\title{
KURIOS
}

(Jurnal Teologi dan Pendidikan Agama Kristen)

Vol. 2, No. 1, Oktober 2014 (57-61)

ISSN 2406-8306 (print)

http://www.sttpb.ac.id/e-journal/index.php/kurios

\section{Kebenaran Tentang Hidup Produktif}

\author{
Yoseph P. Bising \\ Sekolah Tinggi Teologi Pelita Bangsa Jakarta
}

\section{Pendahuluan}

Mengawali dan mengakhiri suatu aktifitas tidak selamanya berjalan dengan mulus, seperti apa yang direncanakan dan diprediksikan sebelumnya. Fakta ini membutuhkan kesadaran dan komitmen serta mentalitas seorang pahlawan yang terus berjuang sampai pada titik darah penghabisan untuk membahagiakan orang-orang yang dikasihinya. Bertanyalah pada diri Anda dalam mengawali tahun ini apa yang akan Anda perbuat bagi diri Anda sendiri untuk menggapai cita-citamu dan apa yang dapat Anda berikan kepada orang-orang yang Anda kasihi. Sudahkah Anda menemukan jawaban atas pertanyaan ini?. Silahkan menjawab dan berkeputusanlah untuk melangkah dan mewujudkan semuanya. Kegagalan Anda pada masa lalu Anda atau pada tahun-tahun yang lalu tidak perlu diratapi. Jangan menjadikan kegagalan Anda pada masa lalu sebagai momok yang menghentikanlangkah Anda, untuk melangkah dalam menggapai impin dan cita-citamu. Kegagalan dimasa lalu bukan merupakan hantu yang menakutkan. Realita hidup membuktikan bahwa kegagalan lebih sering diperbincangkan dan lebih sering dialami. Banyak orang mempersiapkan diri untuk sukses dan lupa mempersikapkan diri untuk menghadapi kegagalan. Hal ini melahirkan orang-orang cenderung frustasi bahkan memilik untuk mengakhiri hidupnya.

Ada banyak orang dalam menjalani proses menuju sukses mengalami ratusan kali kekagalan dalam mewarnai kisah hidupnya, namun persoalanya adalah bukan berapa banyak Anda mengalami kegagalan tetapi bagaimana Anda dapat bangkit disaat kegagaglan itu datang dan bagaiman Anda dapat sukses dihari-hari didepan Anda. Anda tidak tahu kapan hari itu datang, karena itu kerjalah selagi hari masih siang dan jangan biarkan tanganmu berhenti sebab kita tidak tahu kapan sukses itu menjadi milik kita. Jagan pernah berkata apa yang dapat Anda kerjakan sebab disekeliling kita dikelilingi pekerjaan.

Kenali dan temukanlah potensi terbesar dalam diri Anda dan berusaha untuk mengaktualisasikan diri Anda dengan tekun dan kerja keras. Lakukan segala sesuatu tidak 
hanya disaat Anda merasa senang untuk melakukanya. Tetapi lakukalah segala sesuatu disaat Anda tidak senang sekalipun latilah diri Anda untuk melakukan hal-hal mungkin Anda tidak menyukainya, ini merupakan sikap yang membedakan orang-orang sukses.

Kenalilah kelemahanmu dan jangan memberikan peluang kepada kelemahan Anda untuk menghancurkan semua impian Anda. Pengenalan akan kelemahan Anda bukan merupakan kesimpulan dari kegagalan Anda,tetapi merupakan rambu-rambu untuk berhatihati dan berusaha mengaktualisasikan potensi terbesar Anda dalam menjemput impianmu. Menerima kekuatan dan kelemahan Anda tanpa membanding-bangdingkan diri dengan orang lain dan mempersalahkan diri dan orang lain, merupakan sikap pesimis dan mentalitas seorang pecundang yang selalu meratapi kemalanganya. Berbeda dengan orang-orang yang ingin sukses, mereka terus mempertakankan produktifitas untuk terus berjuang mencapai prestasi hidup yang maksimal.

Ubalah sikap Anda, maka hidup Anda akan berubah! Sikap Anda hari ini menentukan sukses Anda di masa depan. Sikap adalah hal terpenting untuk mencapai kepenuhan pribadi dan kesuksesan. Kebiasaanmu adalah pelayan yang paling baik, atau tuan yang paling buruk. Apa yang Anda kerjakan berulang-ulang akan menentukan keberadaanmu. Ubalahkebiasaan yang dapat menghancurkanmu, kerjakan hal-hal yang akan membentuk kebiasaan baru, yang akan membantumu mencapai sukses yang Anda inginkan. Kebiasaan dibentuk dengan latihan. Semakin sulit sesuatu yang kita kerjakan, semakin sulit hal itu kita tinggalkan. Semakin mudah sesuatu yang kita kerjakan, makin sulit hal itu diubah. Siapakah aku? Aku adalah kebiasanku.

Anda Tidak Pernah Dapat Mengubah Hidup Anda Bila Tidak Mengubah Kebiasaan Hari-harimu. Rahasia Kesuksesan Ditemukan Dalam Rutinitas Harianmu. Siapa yang tidak ingin sukses? Suatu pertanyaan yang bodoh. Tetapi, kebanyakan orang yang Anda kenal tidak akan pernah mencapai kesusksesan. Mereka akan memimpikannya, mereka akan membicarakannya. Tetapi, sebagian besar dari mereka tidak akan memperolehnya dan itu benar-benar merupakan hal yang memalukan.

Mengapa hal tersebut dapat terjadi? Karena kebanyakan orang tidak mengerti arti kesuksesan. Kesuksesan itu bukan lotere. Anda dapat mampir disebuah warung dan dalam perjalanan pulang, membeli lotere, lalu menunga datangnya kesuksesaan. Kesuksesan juga tidak diperoleh dengan melakukan praktek-praktek magis. Kesuksesan itu bukan takdir tetapi merupakan hal sehari-hari. Satu-satunya cara untuk mencapai kesuksesan adalah dengan melakukan satu-persatu setiap hari. Kesuksesan bukanlah suatu tujuan yang harus dicapai. Kesuksesan adalah suatu proses perjalanan yang harus dilalui. 


\section{Pembahasan}

Untuk menjadi sukses, Anda tidak perlu beruntung atau kaya. Tetapi Anda perlu mengetahui hal-hal berikut:

1. Anda adalah wujud apa yang Anda lakukan setiap hari

2. Pada mulanya Anda membuat kebiasaan, lambat laun kebiasaan yang akan membentuk Anda

3. Membentuk kebiasaan menuju kesuksesan itu sama mudahnya dengan membentuk kebiasaan yang menuju kepada kegagalan

Setiap hari dalam hidup Anda. Anda sedang dalam proses menuju pada perubahan diri. Apakan Anda berubah untuk menjadi lebih baik atau lebih buruk? Semunya bergantung pada keputusan Anda. Ijinkan saya untuk memberikan beberapa nasihat yang sekiranya mungkin dapat membantu Anda dalam menghadapi semester baru di tahun yang baru ini untuk meraih kesusksesan Anda.

\section{Tujuh Langkah Menuju Sukses}

\section{Buat Komitmen Untuk bertumbuh Setiap hari.}

Salah satu kesalahan terbesar yang dilakukan manusia pada umumnya adalah memiliki fokus yang salah. Ukuran kesusksesan tidak dilihat dari kekayaan, keberhasilan atau kenaikan tingkat. Jika Anda berusaha untuk bertumbuh sedikit saja setiap harinya, Anda akan segera melihat hasil yang positif dalam hidup Anda. Robert Browning dalam puisinya menuliskan bahwa "untuk apa kita hidup di dunia selain untuk bertumbuh?

\section{Menghargai Proses Lebih dari Kejadian}

Kejadian-kejadian dalam kehidupan mendorong kita untuk mengambil keputusan. Padahal proses perubahan dan pertumbuhan yang memiliki nilai berarti. Jika Anda ingin naik kelevel selanjutnya, berjuanglah untuk pertumbuhan yang berkesinambungan.

\section{Jangan Menunggu Inspirasi}

Seorang pemain basket yang handal, Jerry Wels, pernah berkomentar, “Anda tidak akan dapat menyelesaikan pekerjaan-pekerjaan Anda jika Anda bekerja pada saat Anda merasa senang untuk bekerja”. Orang-orang yang meraih keberhasilan mampu melakukannya karena mereka memotivasi diri sendiri dan tetap berusaha sebaik-baiknya bagaimanapun perasaan mereka pada saat itu. Untuk menjadi sukses Anda harus bertekun.

\section{Bersedia Mengorbankan Kesenangan Demi Kesempatan}

Salah satu prinsip hidup yang baik yang perlu Anda bangun adalah prinsip "bayar sekarang; main kemudian”. Untuk segala sesuatu dalam hidup, Anda harus membayar harga. 
Anda dapat memilih untuk membayarnya di muka atau di belakang. Jika Anda membayar di muka, Anda akan mendapat penghargaan pada akhirnya dan penghargaan itu akan terasa lebih manis.

\section{Impikan Sesuatu Yang Besar}

Memimpikan sesuatu yang kecil tidak ada gunanya. Robert J Kriegel dan Lois Patler, dalam bukunya If it aint't broke break it (jika belum pecah, pecahkan saja) kami tidak menemukan batasan dalam diri manusia. semua tes, ukuran, dan garis finis dalam dunia tidak dapat mengukur potensi manusia. ketika seorang mengerjar impiannya, ia akan berusaha sekuat tenaga dan berupaya di luar keterbatasan dirinya. Potensi yang ada dalam diri kita tidak terbatas dan banyak yang belum dimanfaatkan. Jika Anda memikirkan batasan, Anda menciptakan batasan.

\section{Tentukan Prioritas-Prioritas Anda}

Satu kesamaan dari orang yang telah meraih kesuksesan adalah: mereka ahli di dalam mengatur waktu, yang paling utama adalah mereka telah berhasil mengorganisir diri mereka sendiri. Henry Kaiser pendiri Aluminium dan Kaiser Permanente Health care, berkata "setiap menit digunakan untuk perencanaan, memotong, dua menit waktu yang diperlukan untuk pelaksanaannya. Anda tidak akan pernah dapat meraih kembali waktu yang telah terbuang, jadi manfaatkanlah waktu sebaik-baiknya.

\section{Berkorban Untuk Maj}

Tidak ada satupun yang dapat diraih tanpa pengorbanan. Hidup ini penuh dengan saatsaat kritis ketika Anda peroleh kesempatan untuk menukarkan sesuatu yang bernilai demi sesuatu yang lain. Buka mata lebar-lebar untuk saat-saat demikian dan selalu pastikan Anda meraih keuntugan, bukan kerugian.

\section{Penutup}

Jika Anda mendedikasikan diri pada ketujuh langkah ini, Anda akan berkembang dan Anda pasti akan sukses. Pertumbuhan Anda mungkin tidak akan berlangsung kelihatan, tetapi Anda sendiri akan segera melihat kemajuan dalam diri Anda. Walaupun orang tidak dapat melihatnya, jangan kecewa. Teruslah berusaha. Pada akhirnya Anda pasti akan sukses. Di belakang saya ada kekuatan tak terhinga, di hadapan saya ada kemungkinan tanpa akhir. Di sekitar saya ada kesempatan tanpa batas. Apa yang harus aku takuti. Akhir penulisan artikel ini, penulis mengutip beberapa cerita yang dapat memberikan inspirasi dan terus berjuan mencapai sukses di hadapan kita. Sebab orang bijak akan belajar dari kelebihan dan 
kekurangan orang lain, ia tidak melakuakan kesalah yang serupah. Tetapi orang bodoh belajar dari kesalahannnya sendiri.

Belajar Dari Seorang Petani: Seorang pemuda baru saja lulus kuliah jurusan jurnalistik dan memperoleh pekerjaan diperusahaan penerbit surat kabar di sebuah kota kecil. Salah satu tugas awalnya dalah mewawancarai seorang petani tua yang tinggal cukup jauh dari di luar kota. Waktu ia duduk dengan sang petani di serambi depan rumah, wartawan mudah itu melirik ke buku catatannya dan mulai bertanya. Salah satu pertanyaan pertamanya adalah “ pak, pukul berapa Anda berangkat untuk bekerja setiap paginya?"

Sang petani itu tertawa sambil menjawab, "nak, saya tidak berangkat kerja, saya dikeliling oleh pekerjaan saya. Anda berada dimana saja, yang menjadi masalah adalah seringkali kita tidak memiliki mata untuk melihat. Saat Anda menyongsong setiap hari yang baru, pandang sekeliling. Waspadalah jika Anda tidak melihat kesempatan, igatlah bahwa bukan berarti kesempatan itu tidak ada. Anda selalu dikeliling oleh kesempatan. Anda hanya perlu membuka mata dan melihatnya. Lalu segera lakukan sesuatu terhadap kesempatan tersebut.

\section{Bercermin Dan Temukan Cerminan Diri Anda Dalam Cermin}

- Lebih sering memperbaiki dan kuranggi mencela.

- Lebih sering bertindak dan lebih jarang berbicara.

- Lebih sering berkata dapat dilakukan, lebih jarang berkata ini mustahil.

- Lebih sering memberikan inspirasi kepada orang lain, lebih jarang mematahkan harapan orang lain.

- $\quad$ Lebih sering melihat diri, lebih jarang jadi penonton.

- Lebih sering menunjukan apa yang benar, lebih jarang menunjukan apa yang salah.

- Sebih sering menyalakan lilin, lebih jarang mengutuk dalam kegelapan.

\section{Daftar Pustaka}

Harrell, Keith. Ubah Sikap Anda Maka Hidup Anda Akan Berubah, Jakarta: Gramedia, 2007 Mcginnis, Alan Loy. Percaya Diri Vs Kesombongan, Jakarta: Metanoia, 1997.

Maxwell, Jhon C. Success One Day At A Time.Jakarta: Harvest Publication House, 1997. . Developing The Leader Within You, Jakarta: Binarupa Aksara, 1995

Robbins, Anthony. Cara Praktis Mengontrol Mental, Fisik, Emosi dan Keuagan Anda dalam Sekejap, Jakarta: Pustaka Delapratasa, 1997.

Siswanto, Igrea. Kumpulan Cerita-Cerita Yang Membawa Berkat, Jakarta: Metanoia, 2006.

Suwondo, Chandra. Kebiasaan Baik.Jakarta: Metalexia Publishing. 2005.

Vincent Peale, Norman. Berpikir Positif Kunci Sukses, Jakarta: BPK. Gunung Mulia, 2004.

Wahyudi, Iwan S.T. Get Your Wisdom, Jakarta: Metanoia, 2006.

Wijanarko, Jarot. Ttp. Hidup Produktif, Jakarta: Suara Pemulihan. 